\title{
(⿹

\section{Pakkeforløp for pasienter med muskel- og skjelettplager?}

DEBATT

\section{MAY ARNA RISBERG}

E-post: m.a.risberg@nih.no May Arna Risberg er professor og fysioterapeut ved Avdeling for forskning og utvikling (FOU), Ortopedisk klinikk, Oslo universitetssykehus.

Forfatter har fylt ut ICMJE-skjemaet og oppgir ingen interessekonflikter.

\section{INGER HOLM}

Inger Holm er professor og fysioterapeut ved Avdeling for forskning og utvikling (FOU), Ortopedisk klinikk, Oslo universitetssykehus.

Forfatter har fylt ut ICMJE-skjemaet og oppgir ingen interessekonflikter.

\section{LARS ENGEBRETSEN}

Lars Engebretsen er professor og overlege ved Avdeling for forskning og utvikling (FOU), Ortopedisk klinikk, Oslo universitetssykehus.

Forfatter har fylt ut ICMJE-skjemaet og oppgir ingen interessekonflikter.

\section{LARS NORDSLETTEN}

Lars Nordsletten er professor, overlege og leder av Avdeling for forskning og utvikling (FOU), Ortopedisk klinikk, Oslo universitetssykehus.

Forfatter har fylt ut ICMJE-skjemaet og oppgir ingen interessekonflikter.

Flere pasienter med kne- og skulderplager skal behandles konservativt, og primærhelsetjenesten må spille en nøkkelrolle. Pakkeforløp for pasienter med muskel- og skjelettplager kan forhindre overdiagnostikk og overbehandling.

Politikere har etterlyst tiltak for å bedre kvalitet i behandlingen av pasienter med muskelog skjelettlidelser. Pakkeforløp, som først ble innført for kreftsykdommer og nå er under utarbeiding for hjerneslag, kan bedre kvalitet og effektivitet i helsetjenesten og sikre likeverdig utredning og behandling. Til nå har mest oppmerksomhet vært rettet mot behandling i spesialisthelsetjenesten av pasienter med skader, plager og lidelser i muskelog skjelettsystemet, men primærhelsetjenesten må spille en nøkkelrolle for å forhindre overdiagnostikk og bedre kvaliteten på behandling $(1,2)$. Helsedirektoratet har påpekt at kommunene i større grad må ta ansvar for pasienter med muskel- og skjelettlidelser. Det forutsetter tverrfaglige tiltak og samhandling mellom helsetjenestenivåene (3). Pakkeforløp for muskel- og skjelettlidelser kan være riktig vei å gå.

\section{Artrose som eksempel og modell}

Om lag 300 ooo pasienter i Norge har smerter og plager som skyldes artrose, og over 
halvparten av pasientene er i arbeidsfør alder (4). Forekomsten av artrose vil øke i tiden fremover på grunn av $\emptyset \mathrm{kt}$ levealder, overvekt og inaktivitet (5). Førstelinjebehandling for pasienter med kne- og hofteartrose er informasjon (artroseskole), veiledet trening og eventuelt vektreduksjon (6). Altfor få pasienter som kontakter primærhelsetjenesten med artroseplager, blir tilbudt adekvat behandling $(7,8)$. Noen får beskjed om at det ikke er noe å gjøre med, andre blir henvist til MR-undersøkelse og videre til spesialisthelsetjenesten uten å ha blitt skikkelig undersøkt eller fått tilbud om kunnskapsbasert behandling $\mathrm{i}$ primærhelsetjenesten. Aktiv med artrose (AktivA) er en implementeringsmodell for å kvalitetssikre behandlingen til denne store gruppen av pasienter i primærhelsetjenesten, inkludert pasienter med degenerativ meniskskade (www.aktivmedartrose.no).

Artroseskole, og hjelp til selvhjelp, står sentralt for at pasientene skal kunne ta i bruk kunnskap om artrose i dagliglivet. Modellen inkluderer kompetanseheving for fysioterapeuter og et kvalitetsregister for å kunne monitorere behandlingskvaliteten på tvers av helseregioner og kommuner. Så langt har over 8 oo fysioterapeuter fra hele Norge deltatt i AktivA-opplæringen, og over 4 ooo pasienter er inkludert i kvalitetsregisteret. Modellen er utviklet i nært samarbeid med brukere og etter tilsvarende modeller i Sverige (www.boaregistret.se) og Danmark (www.glaid.dk) (9).

AktivA-modellen har stått sentralt i prosessen med å redusere antallet unødvendige kneartroskopier. Modellen gir nettopp denne pasientgruppen et kunnskapsbasert behandlingstilbud. En nylig publisert studie har vist at Helse $\emptyset \emptyset r-\emptyset$ st har lykkes med å redusere overforbruk av kirurgisk behandling (2).

Tilsvarende modeller som AktivA-programmet vil kunne egne seg for flere pasientgrupper med plager, skader og lidelser i muskel- og skjelettsystemet, f.eks. skulder og rygg.

\section{Nasjonale kvalitetsregistre}

Av de 53 nasjonale kvalitetsregistrene dekker stort sett alle behandling i spesialisthelsetjenesten. For å lykkes med å bedre kvaliteten i behandlingen for pasienter med muskel- og skjelettlidelser er det helt nødvendig å ha tilgang til data fra primærhelsetjenesten. Da AktivA-programmet ble startet ved Ortopedisk klinikk ved Oslo universitetssykehus i 2015, var ett av målende å bli det første nasjonale kvalitetsregisteret for pasienter med muskel- og skjelettlidelser behandlet i primærhelsetjenesten. I dag er det etablert gode nasjonale kvalitetsregistre for pasienter med artrose som gjennomgår operasjon med kne- eller hofteprotese, men denne type kirurgi er kun aktuelt for om lag $10 \%$ av alle artrosepasienter. Det haster nå med å monitorere kvaliteten på konservativ behandling i primærhelsetjenesten, der de fleste pasienter skal behandles. Et pakkeforløp inkludert et nasjonalt kvalitetsregister vil være et viktig skritt på veien.

LITTERATUR:

1. Holtedahl R. Atraumatiske kneplager. Tidsskr Nor Legeforen 2018; 138. doi: 10.4045/tidsskr.17.0594. [PubMed][CrossRef]

2. Holtedahl R, Brox JI, Aune AK et al. Changes in the rate of publicly financed knee arthroscopies: an analysis of data from the Norwegian patient registry from 2012 to 2016. BMJ Open 2018; 8: eo21199. [PubMed][CrossRef]

3. Avklaring av ansvars- og oppgavedeling mellom kommunene og spesialisthelsetjenesten på rehabiliteringsområdet. IS-1947. Oslo: Helsedirektoratet, 2012.

https://helsedirektoratet.no/Lists/Publikasjoner/Attachments/189/Avklaring-av-ansvars-og-oppgavedel ing-mellom-kommunene-og-spesialisthelsetjenesten-pa-rehabiliteringsomradet-IS-1947.pdf (1.10.2018).

4. Grotle M, Hagen KB, Natvig B et al. Prevalence and burden of osteoarthritis: results from a population survey in Norway. J Rheumatol 2008;35: 677 - 84. [PubMed] 
5. Bijlsma JW, Berenbaum F, Lafeber FP. Osteoarthritis: an update with relevance for clinical practice. Lancet 2011; 377: 2115 - 26. [PubMed][CrossRef]

6. McAlindon TE, Bannuru RR, Sullivan MC et al. OARSI guidelines for the non-surgical management of knee osteoarthritis. Osteoarthritis Cartilage 2014; 22:363 - 88. [PubMed][CrossRef]

7. Østerås N, Jordan KP, Clausen B et al. Self-reported quality care for knee osteoarthritis: comparisons across Denmark, Norway, Portugal and the UK. RMD Open 2015; 1: eooo136. [PubMed][CrossRef]

8. Nelson AE, Allen KD, Golightly YM et al. A systematic review of recommendations and guidelines for the management of osteoarthritis: The chronic osteoarthritis management initiative of the U.S. bone and joint initiative. Semin Arthritis Rheum 2014; 43: 701 - 12. [PubMed][CrossRef]

9. Skou ST, Roos EM. Good Life with osteoArthritis in Denmark (GLA:D $\left.{ }^{\mathrm{TM}}\right)$ : evidence-based education and supervised neuromuscular exercise delivered by certified physiotherapists nationwide. BMC Musculoskelet Disord 2017; 18: 72. [PubMed][CrossRef]

Publisert:30. oktober 2018. Tidsskr Nor Legeforen. DOI:10.4045/tidsskr.18.0709

Mottatt 11.9.2018, første revisjon innsendt 28.9.2018, godkjent 1.10.2018.

(C) Tidsskrift for Den norske legeforening 2020. Lastet ned fra tidsskriftet.no 